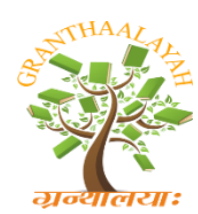

\author{
INTERNATIONAL JOURNAL OF RESEARCH - \\ GRANTHAALAYAH \\ A knowledge Repository
}

Social

\title{
PRESENT EDUCATION SYSTEM AND ITS IMPACT ON THE ECONOMICALLY BACKWARD STUDENTS IN ASSAM
}

\author{
Mangal Sing Kro ${ }^{* 1}$ \\ ${ }^{* 1}$ Gauhati University, India
}

DOI: https://doi.org/10.29121/granthaalayah.v5.i6.2017.2017

\begin{abstract}
The present education system in Assam as well as in the entire country is not satisfactory with respect to modern competitive world. A section of people in our society is on the way to postmodern society whereas; about 30 percent people are still illiterate and are lagging behind. Our country is politically, socially and economically affected due to this unequal distribution of education. The primitive theoretical education system is dominantly occupying in our present education system. This mere theoretical knowledge is not sufficient to cope up with the present real world. The prevailing education system, especially run by the state government could not impart adequate knowledge to its students to compete with the present complex socio-economic sphere. Lack of teaching aids, insufficient practically qualified teacher, and negligence of some important subjects and lack of adequate educational infrastructure fail to make human capital to a required extent in our economy which ultimately acts as one of the factors of poverty unemployment problem. Therefore, our education system should be changed to some extent to be at par with the modern competitive and technological world. The existing problems should be identified and accordingly, proper strategies should be taken to solve these problems.
\end{abstract}

Keywords: Competition; Education; Educational Infrastructure; Impact and Strategy.

Cite This Article: Mangal Sing Kro. (2017). "PRESENT EDUCATION SYSTEM AND ITS IMPACT ON THE ECONOMICALLY BACKWARD STUDENTS IN ASSAM.” International Journal of Research - Granthaalayah, 5(6), 196-201. 10.29121/granthaalayah.v5.i6.2017.2017.

\section{Introduction}

The backbone for the socio-economic development, our education system is lagging behind respect to the present competitive world. Today, the developed countries have about 100 percent literacy rate which leads them to occupy in a better position in developmental indices. But, India has still only 74.04\% (census 2011) which is a matter of concern for the economy. Moreover, all educated or literates may not get a quality education. Therefore, two major problems which spread in India are the lack of quality education and the slow motion in expanding education. Today in this competitive world, making mere literate to the children is not the end for each and 
every parent. How does he or she get literate is a matter of concern. The people who are equipped with quality education get opportunities in a better position and on the other hand, a large number of deprived people are fighting with poverty and unemployment. Education and economic growth are interrelated. Education improves the quality of labour, and also the quality of physical capital through the application of knowledge (Thirlwall, 2006).

In Assam, just a few of the students are receiving education from the institutes where a number of teachers and educational infrastructures are satisfactory. These children are mostly from a sound financial background. These children usually received from highly cost private institutions and from a few of government run schools and colleges. Education here refers to formal education or formal learning. OECD (Organisation for Economic Co-operation and Development) defines formal learning is the learning delivered by trained teachers in a systematic intentional way within a school, academy, college, and institute or in university. The selection procedure for admission in comparatively well- equipped government run schools and colleges is based on percentage getting in qualifying exam and intake capacity. Therefore, a large number of children are obliged to deprive of these facilities. The conditions of government run schools (except Kendriya Vidyalaya, Navodaya Vidyalaya and a few) are not satisfactory with respect to a number of teacher and educational infrastructural facilities. The children from rural areas are mostly prone to suffer. Single teacher school, especially in primary level is one of the important problems of state government run schools. We will discuss briefly the problems pertaining to our education system in the later section.

\section{Objective of the Study}

- To explore the problems of education with respect to teachers and educational infrastructural facilities.

- To explore the problems faced by the children of poor financial background in the existing education system.

\section{Methodology}

This research is based on secondary sources of data and personal observation. Data are collected from government reports, books, journals, official websites and publication of other prestigious institutions. Moreover, although this research is also based on personal observation, hence it is also exploratory in nature.

\section{Result and Discussion}

\subsection{Expenditure on Education as per GDP}

Before going in depth on education scenario in Assam, let us first look at the public expenditure of the Indian government. India is a developing country; therefore, the main problem of this country is how it can develop. Which method of production will bring the development? If the growth rate is fast, then how can it maintain this growth rate for a long period of time so that it can attain in line with developed countries. Although education is the driver for economic development, the expenditure on education should be satisfactory. The developing countries, like 
India, must expend more on education to provide quality education to the children. The public expenditure on education respect to GDP can be shown by a figure.

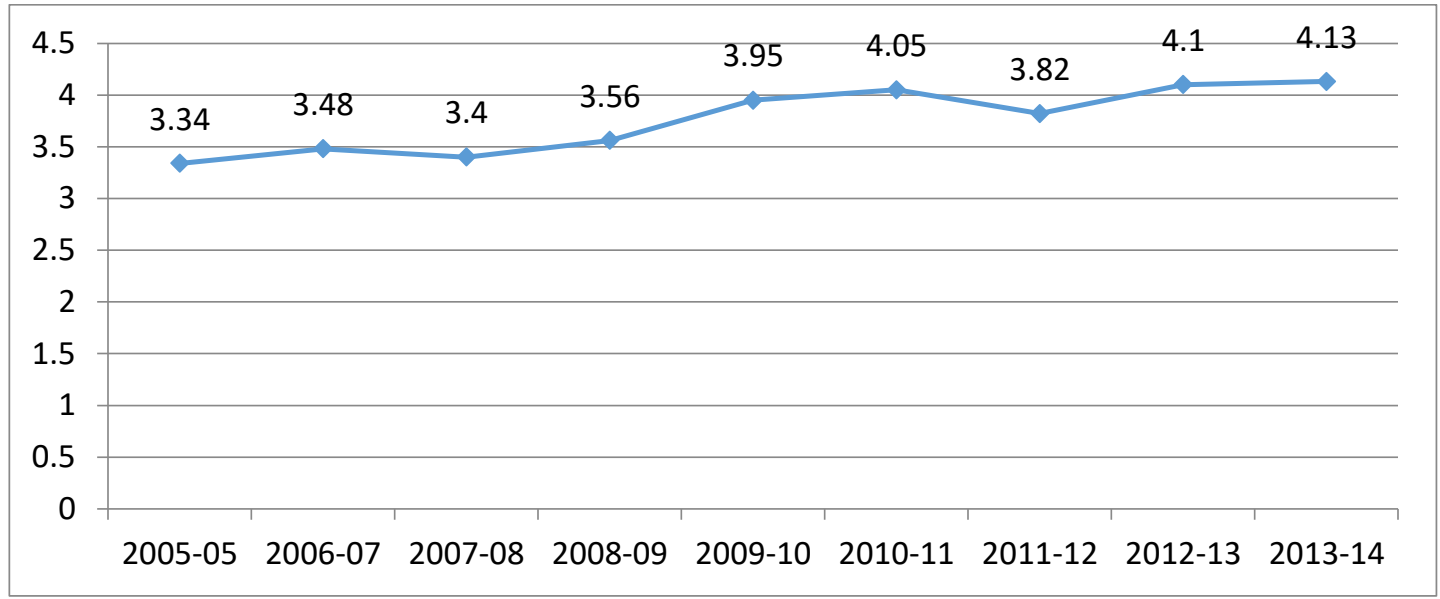

Figure 1: Public expenditure on Education as \% of GDP

Source: Ministry of Human Resource Development, Department of School Education and Literacy, Govt. of India, 2016.

The data reveals that Govt of India's expenditure is less than $4.5 \%$ on education out of total GDP, that is, $3.34 \%$ in $2005-06,4.05 \%$ in $2010-11$ and $4.13 \%$ in $2013-14$ respectively. If we are going to compare with some of the developed countries, then we will find that the expenditure on education by Indian Government is very low. Let us see the scenario of two developed countries, viz., UK and USA; they expend 5.68\% and 5.22\% respectively on education as per GDP 2014 . South Africa, one of the Developing countries expend $6.05 \%$ on education which is higher than India's. Therefore, by observing in the world scenario expenditure on education by the Indian government is very low with respect to its population. India is the second largest populated country in the world after China. The states like Uttar Pradesh, Maharashtra's total population are even higher than some of the countries in the world.

\subsection{Insufficient Teacher and Classroom in Educational Institutions}

A sufficient and the eligible teacher is an utmost important to run an educational Institution smoothly. In this competitive world, each and every teacher should be updated. Mere primitive lecture method, especially in primary and high school level, cannot supply sufficient ingredient to the children. Mere lecture method in the lower classes increases the dropout rate. Because it makes boring the classes for the students and it is sured that children of dropout belong to the poor family background. Therefore, to make class interesting sufficient teaching aids and modern technological equipment is needed. Moreover, sufficient teacher is needed for the wellfunctioning of the school. But, if we are going to see this scenario of Assam, we would be obviously unhappy with this. Let us analyze on the teacher crisis in Assam especially in lower classes. 
Table 1: Enrolment and Teacher in Lower Primary School in Assam, 2014-15

\begin{tabular}{|l|l|l|l|l|l|l|l|}
\hline & \multicolumn{3}{|c|}{ Schools } & Enrolment & \multicolumn{3}{c|}{ Teacher } \\
\hline Assam & Govt./Prov. & $\begin{array}{l}\text { Tea } \\
\text { Garden/Local } \\
\text { Bodies }\end{array}$ & Total & & Gov./Prov. & $\begin{array}{l}\text { Tea } \\
\text { Garden/Local }\end{array}$ & Total \\
\cline { 2 - 8 } & 40017 & 427 & 40444 & 3184037 & 112398 & 1177 & 113575 \\
\hline
\end{tabular}

Source: DISE, 2014-15 (Statistical Handbook Assam, 2015, Government of Assam)

The Lower Primary school generally consists of class I to class V having different subjects, like Drawing, Science, Mathematics, Social Science, English, Hindi, Computer and Regional or Local Language literature. Moreover, games and music are also a part of Lower Primary School. If we are going through the subjects compositions in Lower Primary Schools, a sufficient with the qualified teacher is needed to supply ingredient to the children. But, here in Assam, total 40444 schools with 113575 teachers only, that is, average 2.80 teachers per school according to data 2014-15. Moreover, a sufficient and satisfactory classroom is important for providing good education to the children. Lack of sufficient classroom hampers to their learning. Here, in Assam, the average no. of the classroom in Primary School is only 3 (as par 2014-15) and in upper primary school, its number is 4.5 rooms (as par 2014-15). According to data 2014-15, the dropout rate in Upper Primary school was 7.1 percent. Here, it should be noted that the children of dropout have belonged to either poor economic background or illiterate parents. In Assam, in every stage of formal education, children are obliged to face by the lack of teacher, lack of appropriate classroom and other educational infrastructural facilities.

\subsection{Negligence on Computer Education}

The world is now becoming smaller due to a persistent development of science and Technology. The development of computer is a great contribution to the human society. A large number of the activities can be done by sitting at home through the use of the internet. This is the days of ECommerce, E-Government, E-Banking and so on. The countries are even becoming cash less and less cash economy. But, if we are going to observe in the present education system of Assam, we will find a woeful condition in it. Except for a few private school (where the fees are too high) and Government schools like Kendriya Vidyalaya and Navodaya Vidyalaya, the rest are not equipped with sufficient computer facility and computer education. Therefore, although students of poor economic background cannot afford the cost for these private institutions, they are obliged to deprive of those facilities. Moreover, the admission in KVS and JNV are according to limited intake capacity, therefore, all students cannot take admission in these institutions. Computer education in Assam is still neglecting even in the higher education level in Assam. Dept of Computer Science is rarely seen at the college level.

\subsection{Negligence on Co-Curricular Activities}

Co-Curricular activities are totally neglected in the Education System in Assam. Co-curricular activities are very important for physical development, academic development, aesthetic and 
cultural development and social development. Pointing out its significance the Secondary Education Commission has rightly remarked, "They are as integral a part of the activities of a school as its curricular work and their proper organization needs just as much care and far thought. If they are properly conducted they can help in the development of very valuable attitudes and qualities." Celebrating once a year, like a school week or college week is not sufficient for the students. The regular qualified teacher should be appointed in the educational institutions to bring out hidden talent of the children.

\subsection{Students of Poor Economic Background and Teaching Jobs}

People expect employment after completion of a certain formal education. Most people (especially the poor) in less developed nations do not demand education for its intrinsic noneconomic benefits but simply because it is the only means of securing modern sector employment (Todaro \&Smith, 2011). Therefore, employment is the ultimate destination for the students of poor economic background. But, employment depends on job availability of a state or nation. State, like Assam, is not industrially developed, therefore people mainly depends on service sector for getting the government job. Education Sector is one of the largest job providers in the state, like Assam. But here one question arises that if the education sector is absorbing students from a poor economic background or not.

The Government of Assam has made D.El.Ed. and B.Ed. degree compulsory for teaching from primary to higher secondary level to raise the standard of education. But the problem associated with this initiative is the insufficient government institutions especially B.Ed. College. According to NCTE 2016, a total number of institutes having the facility for B.Ed. degree is 62 and out of these only 13 institutions is under government management and one is under Dibrugarh University Department and the rest are private institutions. Here, the important point must be noted that the government institutes cannot absorb the entire interested candidates although it has limited intake capacity, therefore, students of the poor economic background are obliged to deprive of B.Ed. degree as the fee in private institutes are very high.

Normally the private institutions charge the fee between the ranges of 30 thousand to 70 thousand for the initial year. Therefore, regarding the fee structure of the private colleges, the students of the poor economic background are obliged to deprive of the B.Ed. degree although it is not easy for them to pay such amount per year. This indirect deprivation to the students of poor economic background correspondingly deprives them of teaching jobs in primary and secondary level.

\section{Conclusion}

Education is one of the main sources of human capital formation. Its development brings socioeconomic development. It improves political awareness too. Moral education increases human value in human beings. Therefore, quality education is utmost necessary for the development of a nation as well as the entire world. A quality education can make free a nation from a vicious circle of poverty by a hammer of public expenditure on education. By sowing the seeds of quality education among poor people, upgrades their socio-economic status which ultimately leads to the development of a whole nation. Therefore, to develop a nation the government 
should investigate the problems and accordingly proper strategies should be adopted to solve those problems. The most important point we must be noted that the schools and colleges should be equipped with proper infrastructural facilities with a sufficient and qualified teacher. The government should increase the number of government B.Ed. College with affordable cost. Otherwise, teaching job, especially at the secondary level will be reserved for economically sound people. Moreover, teaching aids and other necessary teaching instruments should be provided to each and every schools and college so that teachers can use these instruments to clarify the concept to the students.

\section{References}

[1] Agarwalla, Dr. Sunita (2016). Education optional for acs mains examination. Guwahati, India: Aditya Book Distributor.

[2] India. Directorate of Economics and Statistics. (2015). Statistical handbook. Retrieved from http://ecostatassam.nic.in/.

[3] India. Ministry of Human Resource Development, Department of School Education and Literacy (2016). Retrieved from http://mhrd.gov.in/school-education.

[4] India. Office of the Register General \& Census Commissioner. (2011). Census Data, Retrieved from http://censusindia.gov.in/.

[5] Thirlwall, A.P. (2006). Growth \& development with special reference to developing economies. New York, America: Palgrave Macmillan.

[6] Todaro Michel P. \& Smith Stephen C. (2011). Economic development. India: Dorling Kindersley (India) Pvt. Ltd.

[7] India. National Council for teacher education. (2017). List of recognized teacher institutions: eastern region. Retrieved from http://www.ercncte.org/b_ed_assam.html.

*Corresponding author.

E-mail address: mangalkro@gmail.com 